This is the accepted manuscript of the article, which has been published in Harlow, C., Leino, P. \& della Cananea, G. (eds) Research Handbook on EU Administrative Law. Cheltenham: Edward Elgar. Research Handbooks in European Law series . ISBN: 978-1-78471-067-5. https://doi.org/10.4337/9781784710682

\title{
Control and scrutiny: parliaments as agents of administrative law
}

\section{Tapio Raunio}

\section{INTRODUCTION}

In academic literature and political debates the notion of parliamentarization of EU governance normally refers to the gradual but consistent empowerment of the European Parliament (EP). Among the various EU institutions, the EP is undoubtedly the one that has changed most over the decades. Initially a purely consultative body with members seconded from national parliaments, the EP is now vested with significant legislative, control and budgetary powers. The Parliament shapes EU laws, particularly through the co-decision procedure (discussed below), is involved in the appointment of the Commission and can force it to resign, and decides on the EU's budget together with the Council. ${ }^{1}$

Concerns about the alleged 'democratic deficit' and legitimacy of European integration were a key driver behind the increased powers of the EP, and the same logic explains also the more recent attention to the role of national parliaments in EU governance. ${ }^{2}$ Long regarded as 'victims' of integration, domestic legislatures have successfully fought back. At the European level, the Maastricht and Amsterdam Treaties in the 1990s included protocols on their information rights and on interparliamentary cooperation, with the Lisbon Treaty even assigning them the right to monitor compliance with subsidiarity through the Early Warning Mechanism (EWM).

Considering the EWM and the broader upgrading of the role of national parliaments by the Lisbon Treaty, it is not surprising that there are stronger expectations regarding domestic legislatures in EU governance. In this new post-Lisbon environment, so the argument goes, domestic legislatures have new tools at their disposal, and this broadened toolkit provides them with incentives to become more strongly involved in EU affairs. However, the analysis in this chapter shows that significant

\footnotetext{
${ }^{1}$ S Hix and R Scully (eds), 'The European Parliament at Fifty' (2003) 41 JCMS 2; R Corbett, F Jacobs and M Shackleton, The European Parliament (8th edn, John Harper Publishing 2011); S Hix and B Høyland, 'Empowerment of the European Parliament' (2013) 16 Annual Review of Political Science, 171; M Kohler, 'European Governance and the European Parliament: From Talking Shop to Legislative Powerhouse' (2014) 52(3) JCMS 600.

${ }^{2}$ B Rittberger, Building Europe's Parliament: Democratic Representation beyond the Nation-State (OUP 2005).
} 
variation between Member State parliaments remains both regarding scrutiny procedures and political motivation, although legislatures throughout the Union have nonetheless gradually learned how to play the European game more effectively. ${ }^{3}$

The EP and national legislatures are also more in contact with one another through various forms of interparliamentary cooperation. Such cooperation has in recent years become particularly relevant in Common Foreign and Security Policy (CFSP $)^{4}$ and economic governance, two highly salient policy fields where parliamentary scrutiny has often been weak. Interparliamentary cooperation has at the same time revealed the tensions between the EP and domestic legislatures but also among the national parliaments themselves. Underlying these tensions are often quite strong differences over the source of legitimacy in modern Europe: while some argue that the EP, as the only directly elected EU institution, is the main forum for aggregating citizens' preferences, others, particularly the more Eurosceptical voices, emphasize the participation rights of national parliaments.

This chapter analyses the roles of the European Parliament and national legislatures in European integration, with particular focus on their individual and collective scrutiny of EU policies. The next two sections examine the various functions the EP and domestic parliaments perform in post-Lisbon Treaty Europe. The challenges involved in interparliamentary cooperation and in scrutiny of CFSP and economic governance are discussed in sections four and five. The concluding discussion underlines the importance of parliamentary debates and argues that while scrutiny, both in terms of legal rights and political motivation, has taken major leaps forward, the multilevel EU governance system presents serious challenges for legislatures, not least regarding informational asymmetries.

\footnotetext{
${ }^{3} \mathrm{C}$ Hefftler, C Neuhold, O Rozenberg and J Smith (eds), The Palgrave Handbook of National Parliaments and the European Union (Palgrave Macmillan 2015).

${ }^{4}$ The term CFSP is used in this chapter to refer to all aspects of EU's foreign and security policy.
} 


\section{THE EUROPEAN PARLIAMENT: EFFECTIVE SCRUTINY, INNOVATIVE PRACTICES}

Members of the European Parliament (MEPs) are often portrayed as federalists interested primarily in gaining more powers for their institution. Such a mind-set is perfectly understandable given that the powers of the EP have always depended on the preferences of national governments in Intergovernmental Conferences (IGC). Not only has the EP succeeded in lobbying, with essentially each round of Treaty revision assigning more competences to the Parliament, but MEPs themselves have proven remarkably inventive in pushing for more powers between IGCs. This pro-active approach applies particularly to accountability of the Commission.

The key to understanding more effective control of the Commission lies in appointment powers, as the link between EP elections and the composition of the Commission has become more direct since the early 1990s. ${ }^{5}$ Because both the Commission and its president must be approved by the Parliament before they can take office (and can also be voted out of office by MEPs), the EP has explicitly demanded that the voice of the voters not be ignored in the make-up of the Commission. Hence the wording of the Lisbon Treaty (Article 17 TEU), according to which the European Council, acting by a qualified majority, 'shall propose to the Parliament' a candidate for Commission president after 'taking into account' the election results merely gave Treaty status to a practice dating back to the mid-1990s.

Before the 2014 elections the Europarties and their EP groups went one step further and put forward 'lead candidates' for the Commission president. This Spitzenkandidaten initiative was criticized heavily by Eurosceptics, with the EP again accused of over-stepping its formal competences. For example, the British Prime Minister David Cameron talked of 'a power grab through the back door' that was never agreed upon by Member States and would both shift power from the European Council to the Parliament and politicize the Commission. ${ }^{6}$ Cameron is certainly right in claiming that the Spitzenkandidaten process will strengthen the role of party politics in the

\footnotetext{
${ }^{5}$ C Moury, 'Explaining the European Parliament's Right to Appoint and Invest the Commission' (2007) 30 WEP 367.

${ }^{6}$ D Cameron, 'No one voted for Mr Juncker', European Voice 13.6.2014.
} 
Commission, but again the change should not be exaggerated. For example, since the 2004 elections, there has been a kind of government-opposition divide in the EP. Because the European People's Party (EPP) is the largest group and centre-right groups control the majority of the seats (and centre-right cabinets dominate the Council), the partisan composition of the Commissions appointed since 2004 has leaned toward the centre-right, with a clear majority of the Commissioners and the president representing either EPP or Alliance of Liberals and Democrats for Europe (ALDE) member parties. Not surprisingly, there has consequently been a firm centre-right grip on EU politics that has unquestionably left its mark on legislation. Whether this undermines the role of the Commission as a neutral upholder of EU law and common interest is open to debate, but at least the Spitzenkandidaten procedure, and more broadly the politicization of the Commission, has the potential to strengthen the 'electoral connection' between voters and Brussels, thus making it easier to assign credit and blame in EU decision-making. ${ }^{7}$ From a more normative viewpoint, one can also argue that since the EU and the Commission already possess significant authority over a broad range of policy areas, the choice of who exercises this authority should be based on competition between political forces, essentially Europarties competing in EP elections. ${ }^{8}$

The stronger electoral and party political connection, together with the increased legislative powers of the Parliament, has brought about much closer interaction with the Commission. There is more informal behind-the-scenes dialogue and Commissioners appear regularly in the plenary and committees - exactly in the same way as happens in national politics between the legislature and the executive branch. ${ }^{9}$ While earlier more confrontational relations have given way to routine interaction, MEPs do subject the Commission to active public scrutiny - and in fact, the party politicization referred to above implies a permanent minority in the chamber less

\footnotetext{
${ }^{7}$ S B Hobolt, 'A Vote for the President? The Role of Spitzenkandidaten in the 2014 European Parliament Elections' (2014) 21 JEPP 1528; H Schmitt, S Hobolt and SA Popa, 'Does Personalization Increase Turnout? Spitzenkandidaten in the 2014 European Parliament Elections' (2015) 16 European Union Politics 347.

${ }^{8}$ A Follesdal and S Hix, 'Why There is a Democratic Deficit in the EU: A Response to Majone and Moravcsik' (2006) 44 JCMS 533; S Hix, What's Wrong With the European Union and How to Fix It (Polity Press 2008).

${ }^{9} \mathrm{M}$ Egeberg, A Gornitzka and J Trondal, 'A Not So Technocratic Executive? Everyday Interaction between the European Parliament and the Commission' (2014) 37 WEP 1.
} 
satisfied with the Commission. ${ }^{10}$ Apart from plenary and committee debates, MEPs use

parliamentary questions for informing the Commission of specific issues and for pushing it into action. Interestingly, written questions seem particularly attractive for MEPs that represent national opposition parties, providing them with an inexpensive channel for alerting (for example) the Commission to domestic problems with transposition of European law or use of EU funds. ${ }^{11}$

While the national governments represented in the European Council are primarily accountable to their individual legislatures (see Section 5), the EP also scrutinizes the summits. ${ }^{12}$ The president of the EP has the right to speak at the start of each European Council meeting, explaining Parliament's positions on the items to be discussed. After the summit the president of the European Council presents a report to the EP plenary on the outcome. And while the political importance of the rotating EU presidency has declined considerably, the prime minister of the country holding the presidency also appears in the plenary to present the priorities for the six-month presidency. Occasionally these plenary debates receive extensive media coverage, as in January 2011 when the Hungarian Prime Minister Viktor Orban, in the Parliament to set out his country’s presidency priorities, was attacked by MEPs for Hungary's controversial new media law. ${ }^{13}$

\section{Committees, Trilogues and Power of the Purse}

Essentially each Treaty revision since the Single European Act (SEA) has brought new legislative powers to the Parliament, with the Lisbon Treaty even extending the co-decision procedure officially called the 'ordinary legislative procedure' - to a large number of new policies including international trade and Common Agricultural Policy (CAP), a policy area known for its strong

\footnotetext{
${ }^{10}$ Through the Lisbon Treaty the Parliament has also stronger means to veto delegated acts of the Commission. In line with Art 290 TFEU, both the EP and Council can revoke the delegation and delegated acts may enter into force only if no objection has been expressed by the Parliament or the Council. However, the Council and the Parliament have made only limited use of these rights. See M Kaeding and K Stack, 'Legislative Scrutiny? The Political Economy and Practice of Legislative Vetoes in the European Union' (2015) 53 JCMS 1268.

${ }^{11}$ S-O Proksch and J Slapin, 'Parliamentary Questions and Oversight in the European Union' (2011) 50 European Journal of Political Research 53; C Jensen, S-O Proksch and J Slapin, 'Parliamentary Questions, Oversight, and National Opposition Status in the European Parliament' (2013) 38 Legislative Studies Quarterly 259.

${ }^{12}$ M Van de Steeg, 'The European Council's Evolving Political Accountability' in M Bovens, D Curtin and P Hart (eds), The Real World of EU Accountability: What Deficit? (OUP 2010) 117-49.

${ }^{13}$ J Chaffin, 'European MPs rap Orban for media law', Financial Times, 20.1.2011.
} 
vested national interests and major budgetary importance. ${ }^{14}$ Hence the EP is now on an almost equal footing with the Council in EU law-making. ${ }^{15}$

As the co-decision procedure has become the standard mode of adopting EU laws, scholars have turned their attention to the political dynamics of this procedure. ${ }^{16}$ The co-decision procedure has resulted in a dramatic increase in interactions between the EP, the Council and the Commission. These repeated interactions, together with concerns over legislative delays, have contributed to the higher rate of early agreements in co-decision procedures. Essentially this means that laws are adopted behind closed doors in informal trilogues. This reduction in inter-institutional rivalry has arguably been a factor in the lack of public debates and the technocratization (or depoliticization) of EU decision-making, trends that have made it more difficult to observe the decisions being made and how the different actors involved in the game participate; ${ }^{17}$ this concern is shared by many backbench MEPs who are dissatisfied with the resulting power shifts inside the chamber. ${ }^{18}$ Currently, an overwhelming majority of co-decision processes are concluded at first reading, signaling a need to study the selection and political profiles and policy influence of the MEPs (in particular, the rapporteurs) who bargain on behalf of the Parliament in trilogues, instead of focusing on the conciliation committees as these groups are now rarely convened. Existing evidence suggests that the rapporteurs, whose reports are the basis of first committee and plenary

\footnotetext{
${ }^{14}$ C Roederer-Rynning and F Schimmelfennig, 'Bringing Codecision to Agriculture: a Hard Case of Parliamentarization' (2012) 19 JEPP 951.

${ }^{15}$ As a result, MEPs are lobbied intensively by interest groups. See for example M Kluger Rasmussen, 'The Battle for Influence: The Politics of Business Lobbying in the European Parliament' (2015) 53 JCMS 365; D Marshall, 'Explaining Interest Group Interactions with Party Group Members in the European Parliament: Dominant Party Groups and Coalition Formation' (2015) 53 JCMS 311; J Beyers, I De Bruycker and I Baller, 'The Alignment of Parties and Interest Groups in EU Legislative Politics. A Tale of Two Different Worlds?' (2015) 22 JEPP 534.

${ }^{16}$ A Rasmussen, 'Twenty Years of Co-decision since Maastricht: Inter- and Intrainstitutional Implications' (2012) 34 Journal of European Integration 735; A Rasmussen, C Burns and C Reh (eds), 'Twenty Years of Legislative Codecision in the European Union: Experience and Implications' (2013) 20 JEPP 7.

${ }^{17}$ M Shackleton and T Raunio, 'Codecision since Amsterdam: a Laboratory for Institutional Innovation and Change' (2003) 10 JEPP 171; but see D Toshkov and A Rasmussen, 'Time to Decide: The Effect of Early Agreements on Legislative Duration in the EU’ (2012) 16 European Integration online Papers (EIoP) 11.

${ }^{18}$ A Héritier and C Reh, 'Codecision and Its Discontents: Intra-Organisational Politics and Institutional Reform in the European Parliament’ (2012) 35 WEP 1134.
} 
deliberations, are the crucial actors in committee and parliamentary decision-making, particularly under the co-decision procedure. ${ }^{19}$

Through the Lisbon Treaty the Parliament also gained the power to approve the entire EU budget together with the Council. The EP and the Council must first approve the multiannual financial framework, negotiated every seven years, that provides the parameters for the subsequent annual EU budgets, which again require the approval of both the EP and the Council. Prior to the Lisbon Treaty the budgetary powers of the Parliament covered only so-called non-compulsory expenditure, roughly half of the annual budget. The 'power of the purse' extends also to the way money is spent. The EP decides on granting the discharge, approving how the annual budget was implemented by the Commission. The Committee on Budgetary Control plays a key role, examining the report and financial accounts of the Commission, the recommendation of the Council, and the report of the Court of Auditors. The Parliament has refused to grant discharge twice, in 1984 and 1998, with the latter resulting in the resignation of the Santer Commission. In a similar manner, the EP must also approve the accounts of other EU bodies, including the Commission, the European Council, the Council, and other agencies. Given the concerns aired about the 'agencification' of EU governance, budgetary power is one of the tools the EP uses in holding such regulatory agencies accountable. ${ }^{20}$

Turning to the EU's external relations, the Parliament enjoys after the Lisbon Treaty substantial legislative rights in international trade and in international agreements. Laws defining the framework for common commercial policy, such as on anti-dumping, are adopted by codecision procedure, and the consent of the EP is required for international agreements concluded in

\footnotetext{
${ }^{19}$ See for example H Farrell and A Hèritier, 'Interorganizational Negotiation and Intraorganizational Power in Shared Decision Making: Early Agreements under Codecision and Their Impact on the European Parliament and Council' (2004) 37 Comparative Political Studies 1184; R Costello and R Thomson, 'The Policy Impact of Leadership in Committees: Rapporteurs' Influence on the European Parliament's Opinions' (2010) 11 European Union Politics 219; A Rasmussen, 'Early Conclusion in Bicameral Bargaining: Evidence from the Co-decision Legislative Procedure of the European Union' (2011) 12 European Union Politics 41; C Reh, 'Is Informal Politics Undemocratic? Trilogues, Early Agreements and the Selection Model of Representation' (2014) 21 JEPP 822.

${ }^{20}$ See for example F Trauner, 'The European Parliament and Agency Control in the Area of Freedom, Security and Justice' (2012) 35 WEP 784.
} 
areas where the ordinary legislative procedure applies. Perhaps more importantly, as in other policy fields where the Parliament has gained powers, stronger legislative rights have contributed to better information rights, with the Commission - that negotiates on behalf of EU - reporting actively to the EP on trade and international agreements, both before and during the negotiations. MEPs have also exploited their new powers, notably when striking down the SWIFT Agreement in February 2010 and the Anti-Counterfeiting Trade Agreement (ACTA) in June 2012. Considering that the EU is the largest trading bloc, through its legislative and veto powers in international trade and other agreements, including accepting new Member States to the Union, the Parliament can also wield at least indirect influence in CFSP, a policy area otherwise largely beyond the reach of MEPs (see Section 5). ${ }^{21}$

More generally, committees are the backbone of the Parliament and the main forum for scrutiny of both legislation and other policies. ${ }^{22}$ Not constrained by government-opposition dynamics, and with the Treaties allowing the Parliament to design its internal rules, the EP has structured and reformed its internal organization to make the most of its hard-won powers in the checks-and-balances EU political system. ${ }^{23}$ In line with the similar empowerment of committees in national legislatures, in the Parliament the full chamber has delegated greater authority to committees. The substance of legislative work is accomplished in committees where individual rapporteurs draft reports that form the basis for parliamentary resolutions. Committee decisionmaking has been characterized as consensual: ${ }^{24}$ pragmatic scrutiny and cooperation between the EPP and the Socialists \& Democrats (S \& D) means that most issues are essentially pre-cooked at

\footnotetext{
${ }^{21}$ A Ripoll Servent, 'The Role of the European Parliament in International Negotiations after Lisbon' (2014) 21 JEPP 568; G Rosén, Striving for Influence: The European Parliament in EU Foreign Policy (ARENA Report No 2/15 2015).

${ }^{22} \mathrm{R}$ Whitaker, The European Parliament's Committees: National Party Control and Legislative Empowerment (Routledge 2011); N Yordanova, Organising the European Parliament: The Role and Legislative Influence of Committees (ECPR Press 2013).

${ }^{23}$ A Kreppel, The European Parliament and Supranational Party System: A Study in Institutional Development (CUP 2002).

${ }^{24}$ P Settembri and C Neuhold, 'Achieving Consensus Through Committees: Does the European Parliament Manage?' (2009) 47 JCMS 127.
} 
the committee stage, thus paving the way for plenary votes adopted by 'supermajorities' ${ }^{25}$

Committees are also key forums for holding institutions such as the Commission and the European

Central Bank (ECB) to account and for shaping the EU's budget and monitoring its implementation.

Committees are well-resourced in terms of staff, and when we include also party group staff, MEPs'

personal assistants (normally three per member) and a research service that provides assistance to

MEPs, it is clear that the Parliament has prioritized policy expertise when deciding its internal organization and rules. ${ }^{26}$ Importantly, committees and obviously the plenary meet in public and hence inject much-needed transparency to EU decision-making.

Finally, the Parliament can set up sub-committees and special temporary committees to deal with specific issues - such as human genetics (2001), the operation of the Echelon interception system (2001), safety at sea (2003), EU future financing (2004 and 2010), CIA rendition of terrorist suspects (2006), climate change (2007), the economic and financial crisis (2009) or tax rulings (2015) - and is entitled since the Maastricht Treaty to establish committees of inquiry to look into alleged contraventions or maladministration in the implementation of EU law. ${ }^{27}$ The EP had set up such committees of inquiry independently even before the Maastricht Treaty entered into force, but has so far established only three formal committees of inquiry: to examine fraud in the 'transit system' for lorries (1995), the mad cow or BSE crisis (1996), and the collapse of the Equitable Life Assurance Society (2005). The challenge with committees of inquiry is that their remit is limited to examining problems related to implementation of EU legislation, whereas

\footnotetext{
${ }^{25}$ S Bowler and G McElroy, 'Political Group Cohesion and 'Hurrah' Voting in the European Parliament' (2015) 22 JEPP 1355.

${ }^{26}$ Policy expertise considerations apply also to rapporteurships, which are distributed among the party groups on the basis of an auction-like points system. While both EP party groups and national parties are using rapporteurships for achieving their policy objectives, the policy expertise of MEPs is also taken into account when allocating reports to MEPs. See for example S Bowler and DM Farrell, 'Legislator Shirking and Voter Monitoring: Impacts of European Parliament Electoral Systems upon Legislator-Voter Relationships’ (1993) 31 JCMS 45; V Mamadouh and T Raunio, 'The Committee System: Powers, Appointments and Report Allocation' (2003) 41 JCMS 333; A Yoshinaka, G McElroy and S Bowler, 'The Appointment of Rapporteurs in the European Parliament' (2010) 35 Legislative Studies Quarterly 457; Whitaker (n 22); W Daniel, 'When the Agent Knows Better than the Principal: The Effect of Education and Seniority on European Parliament Rapporteur Assignment' (2013) 51 JCMS 832; Yordanova (n 22).

${ }^{27}$ M Shackleton, 'The European Parliament's New Committees of Inquiry: Tiger or Paper Tiger?' (1998) 36 JCMS 115.
} 
committees, both standing and temporary ones, have no such limitations. Hence it is not surprising that the EP has made more frequent use of special committees. ${ }^{28}$

The role of national legislatures in European integration first received serious political and academic attention in the mid-1990s in connection with debates on the EU's democratic deficit. Academic interest in the topic drew further inspiration from the first comparative projects that showed domestic legislatures to be largely ineffective or uninterested in controlling their governments in EU matters. ${ }^{29}$ Since then, the role of national parliaments has been a prominent feature of research by parliamentary and EU scholars, with several comparative research projects completed since the turn of the millennium. ${ }^{30}$ This lively academic debate has meant that we are now in a much better position to evaluate the ways in which national legislatures are affected by and become involved in European integration.

It is common to argue that domestic legislatures are the cornerstones of European representative democracy, and given their closer links with citizens, national MPs more than MEPs can contribute to narrowing the gap between EU decision-making and European voters. European integration may not have transformed the basic functions or 'ways of doing things' of national parliaments, but in terms of electoral competition, policy outputs, or constituency interests, Europe

\footnotetext{
${ }^{28}$ The Parliament also has intergroups that unite MEPs with common policy interests. In the 2014-2019 electoral term there are 28 such groups on a range of themes from 'biodiversity, countryside, hunting and recreational fisheries', 'SMEs - Small and medium-sized enterprises' to 'Western Sahara'. Intergroups can also impact on legislation, not least through facilitating flow of policy-specific information among politicians representing different party groups. See $\mathrm{N}$ Ringe, J Victor with C Carman, Bridging the Information Gap: Legislative Member Organizations as Social Networks in the United States and the European Union (University of Michigan Press 2013).

${ }^{29}$ F Laursen and S Pappas (eds), The Changing Role of Parliaments in the European Union (EIPA 1995); P Norton (ed), 'National Parliaments and the European Union' (1995) 1 Journal of Legislative Studies 3; E Smith (ed), National Parliaments as Cornerstones of European Integration (Kluwer Law International 1996).

${ }^{30}$ A Maurer and W Wessels (eds), National Parliaments on their Ways to Europe: Losers or Latecomers? (Nomos 2001); K Auel and A Benz (eds), 'The Europeanisation of Parliamentary Democracy' (2005) 11 Journal of Legislative Studies 3-4; AM Gates, Promoting Unity, Preserving Diversity? Member-State Institutions and European Integration (Lexington Books 2006); J O’Brennan and T Raunio (eds), National Parliaments within the Enlarged European Union: From 'Victims' of Integration to Competitive Actors? (Routledge 2007); O Tans, C Zoethout and J Peters (eds), National Parliaments and European Democracy: A Bottom-up Approach to European Constitutionalism (Europa Law Publishing 2007); G Barrett (ed), National Parliaments and the European Union: The Constitutional Challenge for the Oireachtas and Other Member State Legislatures (Clarus Press 2008); K Auel and T Christiansen (eds), 'After Lisbon: National Parliaments in the European Union' (2015) 38 WEP 2; Hefftler et al (n 3).
} 
simply matters more for national parties and their MPs. And the more Europe matters, the higher the incentives for MPs to scrutinize EU politics. It is thus logical to find stronger parliamentary engagement in EU politics. Indeed, there are good grounds for arguing that the era of 'deparliamentarization', according to which the development of European integration contributed to the erosion of parliamentary control over the executive branch, has ended, or that at the very least we have strong empirical reasons not to portray national legislatures as mere passive victims or losers of European integration. ${ }^{31}$ National MPs have multiple avenues for becoming involved in EU governance, both in the context of their own domestic politics and at the European level. In fact, the toolkit of domestic legislatures resembles a European constitutional smörgåsbord or buffet table with the result that MPs may find it hard to choose which instrument to prioritize.

The function most often emphasized is scrutinizing the government in EU affairs. Indeed, the main Treaty-derived function of national parliaments is to control the governments that represent Member States in the Council and the European Council (Article 10 TEU): 'Citizens are directly represented at Union level in the European Parliament. Member States are represented in the European Council by their Heads of State or Government and in the Council by their governments, themselves democratically accountable either to their national Parliaments, or to their citizens.' Domestic legislatures employ a wide range of control mechanisms for holding the government accountable, but by far the most notable are the European Affairs Committees (EAC). All national parliaments have an EAC, the main function of which is to coordinate parliamentary scrutiny of the government in EU matters. Legislatures have responded to the empowerment of the EU, mainly through upgrading the powers and resources of the EACs and by involving specialized committees more regularly in EU affairs. The delegation of authority from the EAC to specialized committees has been necessitated by the huge workload of the EACs, but is also motivated by the

\footnotetext{
${ }^{31}$ T Raunio and S Hix, 'Backbenchers Learn to Fight Back: European Integration and Parliamentary Government' (2000) 23 WEP 142.
} 
need to utilize the policy expertise of the MPs. Decentralization thus facilitates more informed scrutiny, getting all MPs at least to some extent involved in EU affairs.

Interparliamentary networking in the Conference of Parliamentary Committees for Union Affairs of Parliaments of the European Union (COSAC) - which brings together every six months delegations from EACs and the EP - and other forums has facilitated the sharing of 'best practices', with the individual parliaments assessing the strengths and weaknesses of the scrutiny arrangements in the other legislatures. This learning of best practices is particularly applicable to those countries that have joined the EU since 2004. Indeed, evidence from these newer Member States indicates that their parliaments have on average implemented more comprehensive scrutiny mechanisms than the legislatures of the older EU countries. Notwithstanding the general trend towards tighter scrutiny, there remain strong national differences as to both how powerful national parliaments and their EACs are vis-à-vis the executive and the extent to which the regular standing committees or the plenary become involved in EU affairs. Moreover, despite institutional convergence among the 28 parliaments, the variation also applies to parliamentary scrutiny methods, with some legislatures opting for the famous 'mandating' model where Brussels-bound ministers appear in the EAC before attending Council or European Council meetings while others focus more on document-based scrutiny of EU draft legislation in the committees. ${ }^{32}$

At the European level, the Maastricht and Amsterdam Treaties contained protocols and declarations on the information rights of national parliaments and on interparliamentary cooperation, with the European Convention even setting up a specific working group to examine the role of domestic legislatures. The Lisbon Treaty lists the rights and duties of national parliaments, such as to receive EU documents, monitor compliance with the subsidiarity principle, the power of

\footnotetext{
32 J Karlas, 'National Parliamentary Control of EU Affairs: Institutional Design after Enlargement' (2012) 35 WEP 1095; T Winzen, 'National Parliamentary Control of European Union Affairs: A Cross-National and Longitudinal Comparison' (2012) 35 WEP 657; T Winzen, Beyond the Decline of Parliament: European Integration and National Parliamentary Democracy (PhD dissertation, ETH Zürich 2013); T Winzen, 'European Integration and National Parliamentary Oversight Institutions' (2013) 14 European Union Politics 297; K Auel, O Rozenberg and A Tacea, 'To Scrutinise or Not to Scrutinise? Explaining Variation in EU-Related Activities in National Parliaments' (2015) 38 WEP 282; Hefftler et al (n 3).
} 
veto in Treaty reforms or the possibility to engage in interparliamentary networking (Article 12

TEU). There are also two protocols concerning national parliaments attached to the Lisbon Treaty:

Protocol No 1 on the Role of National Parliaments in the European Union and Protocol No 2 on the Application of the Principles of Subsidiarity and Proportionality. The former is designed to make national MPs better informed about the European decision-making process, and essentially strengthens and consolidates similar provisions attached to the Maastricht and Amsterdam Treaties. However, the real novelty of the Lisbon Treaty is the Early Warning Mechanism, with the national legislatures assigned the right to monitor the compliance of initiatives for EU laws with the principle of subsidiarity according to the rules explained in Protocol No. 2. EWM and Creeping Competences

The EWM, and the broader political dialogue, ${ }^{33}$ are interesting as they forge direct links between national parliaments and EU institutions. The EWM effectively introduces a new first stage to the co-decision procedure, with domestic legislatures consulted and even given the right of conditional veto before the EP and the Council start processing the draft. Under this mechanism, a national parliament can, within eight weeks from the date of transmission of a draft legislative act, send the EU institutions (primarily the Commission) a reasoned opinion stating why it considers that the legislative initiative does not comply with the principle of subsidiarity. National parliaments may consult regional parliaments with legislative powers. Each legislature has two votes and in bicameral systems each of the two chambers has one vote. If the reasoned opinions represent at least one-third of all the votes allocated to the national parliaments (one-quarter in the case of draft legislative acts falling under Article 76 TFEU on the area of freedom, security and justice), the draft

\footnotetext{
${ }^{33}$ After the Lisbon Treaty entered into force these two have essentially blended together while remaining formally separate procedures. The Lisbon Treaty improved the rights of national parliaments to receive both legislative and nonlegislative documents directly from the EU institutions, and the Commission had already adopted in May 2006 a Communication to the Council named 'A Citizens' agenda - delivering results for Europe' (COM (2006) 211 final). This stated that it would transmit all new legislative proposals and consultation papers directly to national parliaments, inviting them to react - not only regarding subsidiarity but to the proposals as such. D Jančić, 'The Barroso Initiative: Window Dressing or Democracy Boost?' (2012) 8 Utrecht Law Review 78; D Jančić, 'The Game of Cards: National Parliaments in the EU and the Future of the Early Warning Mechanism and the Political Dialogue' (2015) 52 CML Rev 939.
} 
must be reviewed ('yellow card'). After the review, the Commission may decide to maintain, amend or withdraw the draft.

An additional ('orange card') procedure is in force under the ordinary legislative procedure. If the reasoned opinions represent at least half of the total votes allocated to legislatures the opinions of both national parliaments and the Commission are submitted to the EP and the Council. If 55 per cent of the members of the Council or a simple majority in the EP agree that the proposal breaches the principle of subsidiarity it shall not be given further consideration. Finally, where a national parliament believes that the adopted law infringes the principle of subsidiarity, it may ask its national government to bring a case before the Court of Justice of the European Union (CJEU).

The EWM, which had previously featured in the Constitutional Treaty, was primarily designed to inject legitimacy to European governance. To quote Rittberger it was 'a logical and widely accepted argument that the political institutions that were seen to have suffered most from ever more transfers of sovereignty to the European level - [national parliaments] - should be entitled to have a say regarding the application of the principle of subsidiarity, putting - if deemed necessary - a brake on the appropriation of policy-making competencies by the Commission., 34 Thus the initial predictions concerning the EWM mainly downplayed the added value of the instrument. ${ }^{35}$ The empirical track record shows, however, that parliaments have slowly increased their activity within the mechanism, though with considerable variation between the chambers. ${ }^{36}$ In May 2012, the first yellow card was shown on the Monti II initiative concerning the 'exercise of the right to take collective action within the context of the freedom of establishment and the freedom to

\footnotetext{
${ }^{34}$ Rittberger (n 2) 192.

${ }^{35}$ E.g. P Kiiver, The National Parliaments in the European Union: A Critical View on EU Constitution-Building (Kluwer Law International 2006) 153-68; T Raunio, 'Much Ado About Nothing? National Legislatures in the EU Constitutional Treaty' (2005) 9 EIoP 9.

${ }^{36} \mathrm{~K}$ Gattermann and C Hefftler, 'Beyond Institutional Capacity: Political Motivation and Parliamentary Behaviour in the Early Warning System’ (2015) 38 WEP 305.
} 
provide services'. The second yellow card was wielded against the proposal to establish a European Public Prosecutor's Office (EPPO) in October 2013. ${ }^{37}$

Regardless of whether national parliaments can influence the EU legislative process through yellow or orange cards, the increasing number of reasoned opinions submitted to the Commission shows that many legislatures view the EWM as a worthwhile instrument and appreciate the opportunity to engage in direct dialogue with EU institutions. EWM can provide national parliaments some measure of control over European legislation and 'creeping competences'. Legislatures with weaker participation rights in EU affairs, as in many of the southern Member States, can also submit reasoned opinions in order to put pressure on their own government. Moreover, often parliaments have deliberately adopted a flexible approach to EWM, including substantive policy opinions in their reasoned opinions in the hope of shaping forthcoming legislation. ${ }^{38}$ EWM can improve the quality of EU legislation by forcing the Commission to be more detailed in its justification for new legislative proposals and in general more sensitive to national concerns. ${ }^{39}$ The interparliamentary networking produced by EWM, occurring mainly either online between parliamentary administrations or between the Brussels-based representatives of domestic legislatures, can also result in more regular overall exchange of information among

\footnotetext{
37 The Commission decided to withdraw the Monti II proposal, especially as the chances were high that it would not have made it through the legislative process in the EU even without a yellow card, as there appeared significant objection both in the Council and within the major EP party groups. In the case of EPPO the Commission maintained the proposal. G Barrett, 'Monti II: The Subsidiarity Review Process Comes of Age ... Or Then Again Maybe it Doesn't' (2012) 19 Maastricht Journal of European and Comparative Law 595; F Fabbrini and K Grant, "Yellow Card, But No Foul": The Role of the National Parliaments under the Subsidiarity Protocol and the Commission Proposal for an EU Regulation on the Right to Strike' (2013) 50 CML Rev 115; M Goldoni, 'The Early Warning System and the Monti II Regulation: The Case for a Political Interpretation' (2014) 10 European Constitutional Law Review 1, 90; I Cooper, 'A Yellow Card for the Striker: National Parliaments and the Defeat of EU Legislation on the Right to Strike’ (2015) 22 JEPP 1406; Jančić, 'The Game of Cards' (n 33).

${ }^{38}$ P Kiiver, The Early Warning System for the Principle of Subsidiarity: Constitutional Theory and Empirical Reality (Routledge 2012).

${ }^{39}$ See Kiiver, ibid; I Cooper, 'The Watchdogs of Subsidiarity: National Parliaments and the Logic of Arguing in the EU' (2006) 44 JCMS 281; I Cooper, 'A 'Virtual Third Chamber' for the European Union? National Parliaments after the Treaty of Lisbon' (2012) 35 WEP 441.
} 
national parliaments. In fact, interparliamentary contacts are a prerequisite for the successful use of EWM, and not just in terms of meeting the thresholds for flagging the yellow or orange card. ${ }^{40}$ Perhaps the biggest question mark with the EWM is that through making national parliaments direct participants in the EU's legislative process, it goes in a way against the very principle of parliamentary democracy. The defining criterion of parliamentary democracy is that the government is accountable to the legislature and can be voted out of office by it. The parliament (the principal) delegates policy-making powers to the executive (its agent), which then rules with the support of the legislature. But now the EWM can reverse these roles. Hence lower chambers will probably in most cases send reasoned opinions only if it is also in the interest of their governments. Indeed, some parliaments, such as the Finnish Eduskunta, have explicitly stated that they view any direct links between national parliaments and EU institutions as problematic, emphasizing that domestic legislatures participate in EU politics indirectly through controlling their governments. More generally, sceptical reviews of the EWM criticize the functioning and effectiveness of the mechanism, arguing it is unlikely to have much effect in practice - for example, either through its narrow judicial scope or because of lack of political motivation. However, given the short history of EWM, the arguments and findings of this literature are understandably quite tentative. $^{41}$

\footnotetext{
${ }^{40}$ In practice national parliaments often rely on information and leadership from other legislatures or from their own governments, as the short the time period of eight weeks does not facilitate independent identification of issues that might raise subsidiarity concerns. A Pintz, 'National Parliaments Overcoming Collective Action Problems Inherent in the Early Warning Mechanism: The Cases of Monti II and EPPO' (2014) LUISS School of Government Working Paper Series SOG-WP 22/2014; Cooper (n 37); A-L Högenauer and C Neuhold, 'National Parliaments after Lisbon: Administrations on the Rise?' (2015) 38 WEP 335.

${ }^{41}$ See particularly A Cygan, Accountability, Parliamentarism and Transparency in the EU: The Role of National Parliaments (Edward Elgar 2013); Kiiver (n 38); T Raunio, 'Les parlements nationaux sont-ils mal conseillés? Examen critique du Mécanisme d'alerte précoce' (2013) 20 Revue internationale de politique comparée 73; R Bellamy and S Kröger, 'Domesticating the Democratic Deficit? The Role of National Parliaments in the EU's System of Governance' (2014) 67 Parliamentary Affairs 437; Jančić, 'The Game of Cards' (n 33); P De Wilde and T Raunio, 'Redirecting National Parliaments: Setting Priorities for Involvement in EU Affairs' (2016) Comparative European Politics (forthcoming).
} 
Parliaments are also arenas for public debate, with plenary debates potentially an important mechanism for both holding the government accountable and for deliberating on EU policies. Empirical studies on the communicative function of national parliaments indicate that EU discussions are mainly confined to the relatively closed environment of EACs and other committees. ${ }^{42}$ Most parliaments do nonetheless debate 'high politics' EU issues like Treaty reforms, multi-annual financial frameworks, or the Euro crisis on the floor. ${ }^{43}$

This limited role of the plenary is probably explained by a combination of institutional choices and the interests of political parties, which are evidently related as parties control the parliamentary agenda and design the legislature's rules of procedure. The establishment of EACs reduces the use of plenary, as the former coordinate parliamentary work in EU matters and are normally authorized to speak on behalf of the whole parliament in these issues. MPs often defend committee deliberations (behind closed doors) with the need to further national interests and to allow confidential exchange of views between the cabinet and the legislature. However, the system of delegating EU matters to EAC and other committees also clearly serves the interests of the mainstream parties that are ideologically less cohesive on integration than on traditional socioeconomic issues that dominate domestic political discourse. Avoiding public debates on European integration is thus a logical response from most vote-seeking political parties. Governing parties may have a particular incentive to scrutinize EU issues in committees without public criticism that might damage the reputation of the cabinet. ${ }^{44}$

\footnotetext{
${ }^{42} \mathrm{~K}$ Auel and T Raunio (eds), 'Connecting with the Electorate? Parliamentary Communication in EU Affairs' (2014) 20 Journal of Legislative Studies 1.

${ }^{43}$ See for example S Puntscher, Riekmann and D Wydra, 'Representation in the European State of Emergency: Parliaments against Governments?' (2013) 35 Journal of European Integration 565; A Maatsch, 'Are We All Austerians Now? An Analysis of National Parliamentary Parties' Positioning on Anti-Crisis Measures in the Eurozone' (2014) 21 JEPP 96; F Wendler, 'Justification and Political Polarization in National Parliamentary Debates on EU Treaty Reform' (2014) 21 JEPP 549; C Rauh, 'Communicating Supranational Governance? The Salience of EU Affairs in the German Bundestag, 1991-2013' (2015) 16 European Union Politics 116.

${ }^{44} \mathrm{~K}$ Auel, 'Democratic Accountability and National Parliaments: Redefining the Impact of Parliamentary Scrutiny in EU Affairs' (2007) 13 ELJ 487.
} 
As most of the existing scholarship has focused on oversight procedures, the challenge is to understand which EU matters receive attention from MPs and why. While there are major EU issues ranging from the Euro crisis to Treaty reforms that are salient for all parliaments, the situation is most likely different with ordinary European legislation or other EU policy processes. That is, the salience of such day-to-day EU matters should vary between Member States, depending for example on the structure of the economy or the geographical location of the country. There is evidence that, at least in some Member States, the level of parliamentary scrutiny is explained by the importance of co-decision legislation or the incentives of government and opposition parties. ${ }^{45}$

This brings us to the question about comprehensive or more selective participation strategies. Should parliaments be more selective and focus on those EU issues that are genuinely domestically salient? There is no denying that it can be useful, particularly from the point of view of government accountability, to demand information and hear ministers about all matters on the Council and European Council agendas so that MPs can intervene if needed, but legislatures could surely also engage in more forward-looking issue selection with the help of either national or EU documents such as the Commission's annual legislative programme. The comparative literature referred to above does suggest that parliaments - and particularly their administrations ${ }^{46}-$ do perform such filtering of EU issues, but more could be done to prevent information overload and to facilitate more targeted scrutiny. This would also be beneficial for both government oversight and communicating with citizens, as more attention would be given to those matters that are domestically salient. As argued convincingly by Winzen:

<quotation> What would it really tell us, if we were to find that parliaments examine each and every of the EU's legislative proposals in detail, instructing the government what goals to pursue in the negotiations? ... The benchmark for well-functioning

\footnotetext{
${ }^{45}$ R De Ruiter, 'Under the Radar? National Parliaments and the Ordinary Legislative Procedure in the European Union' (2013) 20 JEPP 1196; D Finke and T Dannwolf, 'Domestic Scrutiny of European Union Politics: Between Whistle Blowing and Opposition Control’ (2013) 52 European Journal of Political Research 715; D Finke and A Herbel, 'Beyond Rules and Resources: Parliamentary Scrutiny of EU Policy Proposals' (2015) 16 European Union Politics 490. ${ }^{46}$ Högenauer and Neuhold (n 40).
} 
oversight institutions in EU affairs is not that they exacerbate time shortages by making parliament deal with all EU activities, but to help parliament put the time it devotes to EU affairs to the best use. Thus, oversight institutions should help parliaments select the matters that are worth the parliament's time. ${ }^{47}</$ quotation $>$ To summarize, national legislatures, once described as losers of integration, have fought back and have in many ways become better at controlling governments in European affairs, with the Treaty provisions further consolidating their position in EU governance. ${ }^{48}$ It is at the same time important to remember that while both national constitutions and EU Treaties provide the legal framework for national parliamentary involvement, domestic legislatures are nonetheless as national institutions rather free to decide whether and how to process European matters. Direct links with EU institutions, including the EWM, are voluntary, and even when national laws dictate the formal procedures for parliamentary EU scrutiny, it is up to MPs to decide which European issues deserve closer attention. The strong differences between the legislatures indicate varying motivation to become engaged in EU affairs and/or that the parliamentary scrutiny procedures leave room for improvement. Furthermore, European integration continues to move forward and places ever more serious demands and constraints on domestic legislatures. This applies particularly to the Euro crisis and European economic governance, where key decisions about national macro-economic policies are taken in the European Council and the European Semester (see Section 5).

\footnotetext{
${ }^{47}$ Winzen, Beyond the Decline of Parliament (n 32) 153.

${ }^{48}$ Domestic scrutiny can also facilitate transposition of European laws, with effective ex ante parliamentary involvement correlated with better implementation rates of EU directives. This point is important, for all too often active scrutiny by individual parliaments has been viewed as something evil (particularly by those who favour deeper integration), slowing down or even blocking EU decision-making through reducing the bargaining range of national governments. See T Bergman, 'The European Union as the Next Step of Delegation and Accountability' (2000) 37(3) European Journal of Political Research 415; L Martin, Democratic Commitments: Legislatures and International Cooperation (Princeton University Press 2000) 164-89; C Sprungk, 'Legislative Transposition of Directives: Exploring the Other Role of National Parliaments in the European Union' (2013) 51 JCMS 298; D Finke and T Dannwolf, 'Who Let the Dogs Out? The Effect of Parliamentary Scrutiny on Compliance with EU law' (2015) 22 JEPP 1127.
} 
The EU has introduced a new dimension to parliamentary work by facilitating more active international networking. ${ }^{49}$ Legislatures engage in EU politics in both bilateral - between individual parliaments or between a domestic legislature and the EP - and multilateral interparliamentary cooperation, with the latter exercised mainly through COSAC. The advantages of interparliamentary networking appear obvious. Meetings of national MPs contribute to the sharing of best practices and the identification of mutual problems and particularly through regular dialogue with MEPs, MPs receive information that contributes to effective government scrutiny. Online platforms such as IPEX (InterParliamentary EU information exchange), essentially a database for the exchange of views among parliaments on draft EU legislation, including opinions submitted under the EWM, are also beneficial. Crum and Fossum even envision a 'multi-level parliamentary field', but real-life experiences paint a more sober picture. ${ }^{50}$

Inter-parliamentary contacts have become more regular over the years, ${ }^{51}$ but there are limits to such networking. ${ }^{52}$ The calendars of parliamentarians are quite full, and timetabling problems are one of the reasons why most legislatures and their committees seldom invite MEPs to their meetings. More importantly, there seems to be a potentially misplaced assumption in the literature that interparliamentary ties would necessarily benefit MPs' policy expertise. There is

\footnotetext{
${ }^{49} \mathrm{~T}$ Raunio, 'The Gatekeepers of European Integration? The Functions of National Parliaments in the EU Political System' (2011) 33 Journal of European Integration 303; C Sprungk, 'A New Type of Representative Democracy? Reconsidering the Role of National Parliaments in the European Union' (2013) 35 Journal of European Integration 547.

${ }^{50}$ B Crum and J E Fossum, 'The Multilevel Parliamentary Field: A Framework for Theorizing Representative Democracy in the EU' (2009) 1 European Political Science Review 249.

${ }^{51}$ E.g. K Neunreither, 'The European Parliament and National Parliaments: Conflict or Cooperation?' (2005) 11 Journal of Legislative Studies 466; C Fasone, 'Interparliamentary Cooperation and Democratic Representation in the European Union' in S Kröger and D Friedrich (eds), The Challenge of Democratic Representation in the European Union (Palgrave Macmillan 2012) 41-58; B Crum and J E Fossum (eds), Practices of Inter-Parliamentary Coordination in International Politics: The European Union and beyond (ECPR Press 2013); C Hefftler and K Gattermann, 'Interparliamentary Cooperation in the European Union: Patterns, Problems and Potential' in C Hefftler, C Neuhold, O Rozenberg and J Smith (eds), The Palgrave Handbook of National Parliaments and the European Union (Palgrave Macmillan 2015) 94-115.

${ }^{52}$ Kiiver (n 35) 115-32.
} 
some evidence that interparliamentary networking can improve scrutiny of the government, ${ }^{53}$ but surely MPs can get relevant information more easily from other sources: from national ministries, interest groups, direct contacts with EU institutions, or indeed from social media. Especially MPs of the governing parties can always benefit from links with the executive branch, and both government and opposition parties can involve MEPs in the work of party organs. Nor is there political will for changing the powers of various interparliamentary bodies, the decisions of which are purely nonbinding. While interparliamentary cooperation has thus become institutionalized and brings added value to the legislatures and their EACs, the available evidence also indicates that the current forms and levels of such cooperation are unlikely to change in the future.

Recent years have witnessed the establishment of two new Treaty-derived interparliamentary conferences: the Inter-Parliamentary Conference for the Common Foreign and Security Policy and the Common Security and Defence Policy (CFSP/CSDP) which met for the first time in 2012, and the 'Article 13 conference', named after the Article in the Fiscal Compact (Treaty on Stability, Coordination and Governance in the Economic and Monetary Union) which provided the legal framework for the Interparliamentary Conference on Economic and Financial Governance of the European Union that convened for the first time in 2013. The latter conference in particular has been so far plagued with conflicting visions of appropriate level of scrutiny, with the EP and its allies favouring weak conferences with limited powers whereas some national legislatures support stronger conferences equipped with broad mandates. ${ }^{54}$ Not that much appears to have changed since the so-called Assizes, the first joint conference of the EP and national parliaments convened in 1990, when proceedings were dominated by the EP delegation, with several domestic legislatures feeling that the EP had used the conference to further its own objectives. Nonetheless, the decision

\footnotetext{
${ }^{53}$ E Miklin, 'Inter-parliamentary Cooperation in EU Affairs and the Austrian Parliament: Empowering the Opposition?' (2013) 19 Journal of Legislative Studies 22.

${ }^{54}$ I Cooper, 'Parliamentary Oversight of the EU after the Crisis: On the Creation of the 'Article 13' Interparliamentary Conference' (2014) LUISS School of Government Working Paper Series SOG-WP21/2014; A Herranz-Surrallés, 'The EU's Multilevel Parliamentary (Battle)Field: Inter-parliamentary Cooperation and Conflict in Foreign and Security Policy' (2014) 37 WEP 957.
} 
to set up conferences in the fields of economic governance and CFSP indicates the challenges parliaments face in scrutiny of these two highly salient policy areas.

Foreign and economic policies are often identified as issues where democratic accountability is weak. But what accounts for the allegedly low level of parliamentary influence? The literature on foreign policy suggests two interconnected explanations: either legislatures voluntarily acquiesce to such government-driven policy-making or they simply fail to control the cabinet in external relations. ${ }^{55}$ However, beyond the very specific case of the US Congress legislative-executive relations in the realm of foreign and security policy have attracted remarkably little scholarly attention. A number of studies have examined parliamentary powers over troop deployments. International obligations and joint military missions, coordinated primarily by North Atlantic Treaty Organization (NATO), the United Nations (UN), and the EU, or collective defence clauses create challenges for parliamentary involvement. In the context of accession to NATO and the EU, many Central and Eastern European states relaxed their parliamentary restrictions and abolished their parliamentary provisos for NATO and EU operations. ${ }^{56}$ Another emerging strand of work has begun to examine scrutiny of CFSP, indicating strong variation between legislatures. The in-depth comparison of selected parliaments by Huff revealed considerable differences between legislatures, with some, such as the Dutch Tweede Kamer or the German Bundestag, displaying active

\footnotetext{
${ }^{55}$ See T Raunio, 'Legislatures and Foreign Policy' in S Martin, T Saalfeld and K W Strøm (eds), The Oxford Handbook of Legislative Studies (OUP 2014) 543-66; T Raunio and W Wagner, 'Legislative-Executive Relations in Foreign and Security Policy' (2015) Paper presented at the Workshop on Legislative-Executive Relations in Foreign and Security Policy, 21-22.5.2015, Amsterdam.

${ }^{56}$ H Born and H Hänggi (eds), The 'Double Democratic Deficit': Parliamentary Accountability and the Use of Force Under International Auspices (Ashgate 2004); D Peters and W Wagner, 'Between Military Efficiency and Democratic Legitimacy: Mapping Parliamentary War Powers in Contemporary Democracies, 1989-2004' (2011) 64 Parliamentary Affairs 175; PA Mello, Democratic Participation in Armed Conflict: Military Involvement in Kosovo, Afghanistan and Iraq (Palgrave Macmillan 2014); D Peters and W Wagner, 'Executive Privilege or Parliamentary Proviso? Exploring the Sources of Parliamentary War Powers' (2014) 40 Armed Forces \& Society 310; S Dieterich, H Hummel and S Marschall, 'Bringing Democracy Back In: The Democratic Peace, Parliamentary War Powers and European Participation in the 2003 Iraq War' (2015) 50 Cooperation and Conflict 876.
} 
engagement in CFSP matters, whereas other legislatures are lagging behind both in terms of efficient scrutiny procedures or political will. ${ }^{57}$

The European Parliament is in turn quite sidelined from foreign and security policy. Essentially the Parliament debates and adopts resolutions on the CFSP, can, in line with Article 36 TEU, put questions to and engage in a dialogue with the EU's foreign minister (High Representative of the Union for Foreign Affairs and Security Policy who is also a Vice-President of the Commission) and the other EU institutions over various CFSP matters, for example through Joint Consultation Meetings (JCMs) with the Council, the European External Action Service (EEAS) and the Commission. However, while the EP brings much-needed transparency to CFSP through its debating function, the main instruments of the Parliament in CFSP are nonetheless more indirect in kind. Through its legislative powers in trade and development policy and its powers to strike down international agreements, the EP can exert pressure on third countries and international organizations, for example regarding human rights where the Parliament has shown notable activism (including its annual Sakharov Prize for Freedom of Thought). Another avenue of influence for both national legislatures and the EP is money, as the latter must approve the annual CFSP budget. ${ }^{58}$ Again committees are the central actors: notably the Committee on Foreign Affairs and its two subcommittees (on Security and Defence and on Human Rights), Committee on International Trade and Committee on Development. The EP also has a large number of delegations to international or regional parliamentary assemblies (such as the ACP-EU Joint Parliamentary Assembly and EuroLat) and individual third countries, through which MEPs can exercise

\footnotetext{
${ }^{57}$ A Huff, 'Executive Privilege Reaffirmed? Parliamentary Scrutiny of the CFSP and CSDP' (2015) 38 WEP 396. See also D Peters, W Wagner and N Deitelhoff (eds), The Parliamentary Control of European Security Policy (ARENA Report No 7/08 2008).

${ }^{58} \mathrm{~J}$ Smith, A Huff and G Edwards, Towards a More Comprehensive, Strategic and Cost-effective EU Foreign Policy: The Role of National Parliaments and the European Parliament (European Parliament, Directorate General for Internal Policies, Policy Department D: Budgetary Affairs 2012); Rosén (n 21).
} 
'parliamentary diplomacy' and networking. Party groups also have their own international contacts, not least with sister parties from non-EU countries. ${ }^{59}$

In European economic governance the challenge for parliamentary scrutiny lies more in the dynamics of the decision process, the blurring of competences between national and European institutions, and the multiplicity of actors involved, particularly since the onset of the Euro crisis. ${ }^{60}$ Constitutionally domestic legislatures are in a strong position, as their consent is required for Treaty revision and other issues decided by unanimity — including the adoption of new intergovernmental measures aiming at more effective economic governance in the EU and the Eurozone. The European Parliament, in turn, finds itself in a rather similar position to that in CFSP: it enjoys limited legislative powers and is kept 'in the loop', but otherwise decision-making is dominated by the Council, the European Council and the Commission. At the same time legislatures across the Union have questioned whether they can genuinely debate and examine the issues, a concern that is understandable given the complexity of the situation, the need by the Member States to achieve quick results, and the high number of European Council and other EU meetings that deal with the Euro crisis.

Parliamentary scrutiny of EMU is closely linked to the accountability of the European Council, the powers and activity of which have increased tremendously in European economic governance. Key decisions about the bailouts of Greece and other Member States, the creation of the banking union and European Semester are all made in the European Council. With the entry into force of the Fiscal Compact, there are now specific Eurozone summits and national budgets coordinated in yearly 'European Semesters'. These include strong Council and Commission recommendations regarding national budgets with sanctions possible should these not be heeded.

\footnotetext{
${ }^{59}$ See for example B Crum, 'Parliamentarization of the CFSP through Informal Institution-making? The Fifth European Parliament and the EU High Representative' (2006) 13 JEPP 383; M Riddervold and G Rosén, 'Beyond Intergovernmental Cooperation: The Influence of the European Parliament and the Commission on EU Foreign and Security Policies' (2015) 20 European Foreign Affairs Review 399; G Rosén, 'EU Confidential: The European Parliament's Involvement in EU Security and Defence Policy’ (2015) 53 JCMS 383; Rosén (n 21); S Stavridis and D Irrera (eds), The European Parliament and its International Relations (Routledge 2015).

${ }^{60}$ The discussion on national parliamentary scrutiny of European Council and economic governance draws on De Wilde and Raunio (n 41).
} 
While most domestic legislatures have set up mechanisms to deal with European Council affairs, much of parliamentary oversight remains geared to the ordinary legislative procedure, scrutinizing Commission proposals and government behaviour in the Council. Some generally more 'Europeanized' parliaments, like the Danish Folketing, the Dutch Tweede Kamer and those of the Baltic states also enjoy substantial scrutiny powers over European Council meetings. But this is not common, as according to a detailed study conducted in 2012 only 17 of 27 national parliaments had formal rules dealing specifically with European Council meetings. ${ }^{61}$

Under the European Semester, national governments are asked to send plans for longterm budgetary planning - Stability or Convergence Programmes (SCPs) - to the Commission for recommendations and deliberation in the Council. It appears that neither these national plans nor the European level recommendations and deliberations receive sufficient attention from national MPs. Though there are special committee meetings surrounding the submission of SCPs in some parliaments, public activity is almost fully lacking, and there is considerable variation between the legislatures. Overall, the Euro crisis and reformed Euro area governance seem to have accentuated the differences between more active and weaker legislatures, with the latter in particular struggling to establish any real control over Euro area decisions. ${ }^{62}$ The inevitable conclusion must be that domestic parliamentary scrutiny of European economic governance is far from optimal.

The European Parliament has gradually strengthened its role in economic governance. Its approval is needed for laws on macroeconomic surveillance such as the 'six pack' and 'two pack' regulations and directives. Beyond such legislative tools, the Parliament basically enjoys

\footnotetext{
${ }^{61} \mathrm{~W}$ Wessels, O Rozenberg, M Van Den Berge, C Hefftler, V Kreilinger and L Ventura, Democratic Control in the Member States of the European Council and the Euro Zone Summits (European Parliament, Directorate-General for Internal Policies, Policy Department C: Citizen's Rights and Constitutional Affairs 2013).

${ }^{62}$ A Benz, 'An Asymmetric Two-Level Game: Parliaments in the Euro Crisis' in B Crum and J E Fossum (eds), Practices of Inter-parliamentary Coordination in International Politics: the European Union and beyond (ECPR Press 2013) 125-40; C Deubner, 'The Difficult Role of Parliaments in the Reformed Governance of the European Economic and Monetary Union' (Foundation for European Progressive Studies (FEPS) Study No 19, August 2013); K Auel and O Höing, 'Parliaments in the Euro Crisis: Can the Losers of Integration Still Fight Back?' (2014) 52 JCMS 1184; K Auel and O Höing, 'National Parliaments and the Eurozone Crisis: Taking Ownership in Difficult Times?' (2015) 38 WEP 3755; B Rittberger and T Winzen, 'Parlamentarismus nach der Krise: Die Vertiefung parlamentarischer Asymmetrie in der reformierten Wirtschafts- und Währungsunion’ (2015) 56 Politische Vierteljahresschrift 430.
} 
rather broad information rights. This applies to the European Semester, where the EP can organize hearings and express its opinions. The ECB reports to the EP regularly, including annual reports on monetary policy and a supervisory report. However, as with CFSP, policy-making is nonetheless still largely intergovernmental and thus beyond direct EP influence. ${ }^{63}$

6. CONCLUDING DISCUSSION

This overview of parliamentary control shows that European parliaments are becoming more strongly involved in EU governance and are taking on the task of a more penetrating scrutiny function. In so doing parliamentary bodies, most notably committees, are taking over some of the control functions traditionally associated with administrative law. This applies especially to the European Parliament which has grown from a 'talking shop' to a real legislature, participating fully in law-making processes and enjoying budgetary powers that it has used skillfully to extend its control and supervision of executive functions. The EP deserves credit not only for innovative design of its own rules of procedure, but also for establishing pro-actively scrutiny practices that either have later received Treaty status or otherwise provide MEPs with new avenues to influence the EU policy process. Importantly, and no doubt linked to the empowerment of the institution, turnover of MEPs has decreased with a higher share of politicians building careers in the EP - with these individuals also more likely to wield influence in the Parliament through holding leadership positions or acting as rapporteurs. ${ }^{64}$ This contributes both to the policy expertise in the Parliament and to the scrutiny it carries out vis-à-vis the other EU institutions.

For national parliaments the situation is more diverse. Overall, they certainly subject their governments to tighter scrutiny in EU affairs than before, but much variation remains - both regarding the efficiency of scrutiny mechanisms and the political will to become engaged in European issues. Perhaps we should be realistic and not expect too much from national parliaments.

\footnotetext{
${ }^{63}$ C Lord, 'The European Parliament in the Economic Governance of the EU' (2003) 41 JCMS 249; B Rittberger, 'Integration without Representation? The European Parliament and the Reform of Economic Governance in the EU' (2014) 52 JCMS 1174.

${ }^{64} \mathrm{R}$ Whitaker, 'Tenure, Turnover and Careers in the European Parliament: MEPs as Policy-seekers' (2014) 21 JEPP 1509; WT Daniel, Career Behaviour and the European Parliament: All Roads Lead through Brussels? (OUP 2015).
} 
Legislators face competing demands on their time, and despite the increasing relevance of Europe, it is completely logical for MPs and for the whole parliament to delegate many EU matters to governments and to become only selectively involved in European affairs. European integration is also continually evolving, with increasing policy constraints on domestic legislatures, particularly regarding macroeconomic and budgetary policy-making.

Parliaments have a buffet table of avenues to influence the EU policy cycle, but more avenues does not necessarily translate into more influence. Here lessons from multilevel governance (MLG) theorizing seem relevant. According to this framework, the modern regional or global political architecture offers actors such as legislatures multiple access points to influence politics. But the main lesson of the MLG is a more negative one, indicating that legislatures tend to be excluded from intergovernmental policy coordination and negotiations that dominate decisionmaking in multilevel systems of government such as the EU. Several scholars have argued admittedly often without much real empirical evidence — that multilevel governance involves the sharing of policy competencies by actors at different levels, muddled lines of accountability, and the marginalization of representative bodies. ${ }^{65}$ Legislatures have responded in part through more regular interparliamentary cooperation, and it is not surprising that such interparliamentary networking is particularly pronounced in CFSP and EMU, two policy areas where informational asymmetries seem particularly challenging. Both are also policy areas where policy-making is still primarily intergovernmental but with stronger supranational elements, exposing thus institutional rivalry between domestic legislatures and the European Parliament.

This chapter has understandably focused on the scrutiny and control function of parliaments, but these may not be the most important contributions MPs or MEPs can make to EU governance. Indeed, the lack of (domestic) debates on Europe is often seen as a significant

\footnotetext{
${ }^{65}$ I Bache and M Flinders (eds), Multi-level Governance (OUP 2004); A Benz and Y Papadopoulos (eds), Governance and Democracy: Comparing National, European and International Experiences (Routledge, 2006); A Benz, C Harlow and Y Papadopoulos (eds), 'Accountability in EU Multilevel Governance' (2007) 13 ELJ 4; D Curtin, P Mair and Y Papadopoulos (eds), 'Accountability and European Governance' (2010) 33 WEP 5; R Bellamy (ed), 'Symposium on Democracy and New Modes of Governance’ (2011) 46 Government and Opposition 1.
} 
component of the democratic deficit. For example, the late Peter Mair argued convincingly that European integration contributed to the depoliticization or 'hollowing out' of modern European governance and particularly of national democracy. ${ }^{66}$ While we have to be careful not to exaggerate the role of parliamentary debates, at the very least they provide the electorate with the opportunity to learn what is on the agenda of European politics and what are the positions of parties in these matters, particularly if the debates are covered by the media. Nor should one assume that such parliamentary debates will result in greater public support for the EU, but they do improve the democratic quality of both national and EU governance. As the Euro crisis demonstrates, in the short run parliamentary debates may even act as a brake on further integration through setting tighter constraints on national EU policy, but in the long run such debates will create the basis for a more democratic Europe.

${ }^{66}$ P Mair, 'Political Opposition and the European Union' (2007) 42 Government and Opposition 1. 